\title{
Incidence of NUT carcinoma in Western Australia from 1989 to 2014: a review of pediatric and adolescent cases from Perth Children's Hospital
}

Tina Carter ${ }^{1,2,3}$, Maxine Crook ${ }^{1,2}$, Ashleigh Murch², Alex H. Beesley ${ }^{3}$, Nick de Klerk ${ }^{3}$, Adrian Charles ${ }^{1,2,4}$ and Ursula R. Kees ${ }^{3^{*}}$

\begin{abstract}
Background: NUT carcinoma (NC), previously known as NUT midline carcinoma, is a rare and very aggressive cancer that occurs in both children and adults. NC is largely chemoresistant, with an overall survival of less than 7 months. Because the carcinoma is not restricted to a particular organ, diagnosis is often a challenge. In the absence of a clearly determined incidence for NC, we sought to study the diagnosis of patients in a well-defined population.

Methods: We systematically reviewed records of all patients that presented to the Oncology Department of the Princess Margaret Hospital for Children from 1989 to 2014. This institution in the geographically isolated state of Western Australia has a catchment population of around 2 million. We then identified all high grade undifferentiated sarcomas or carcinomas in the 0-16 year age group.

Results: Over 26 years, we found 14 patients of 16 years or younger with undifferentiated malignant tumors. Of these, five tumors were positive by immunohistochemistry for the NUT/NUTM1 (Nuclear Protein in Testis) protein and/or the translocation $\mathrm{t}(15 ; 19)$. Three patients presented with thoracic tumors, one with a para-spinal tumor, and one had an upper airway nasopharyngeal carcinoma. In all five cases, there was an initial response to therapy and then progression. This 26-year survey was conducted in a geographically isolated state with a well-defined population, and we determined an estimated incidence of NC of around 0.41 per million child years ( $0-16 \mathrm{yrs}$. of age) at risk. From three patients it was feasible to derive cell lines for further genetic analyses and drug screening.

Conclusions: For the first time, the incidence of NC could be determined in a well-defined geographic area. The calculated rate of NC incidence is consistent with a history of under-recognition for this malignancy. These findings indicate that improved diagnostic detection of NC would enable better management and counselling of patients. Our findings emphasize the heterogeneity of $\mathrm{NC}$, and they highlight the need to develop personalised therapy options, and to consider a diagnosis of NC in undifferentiated malignant tumors.
\end{abstract}

Keywords: NC incidence, Carcinoma, Undifferentiated malignancy, NUTM1, Heterogeneity, Diagnosis, Rare, Aggressive

\footnotetext{
* Correspondence: Ursula.Kees@telethonkids.org.au

${ }^{3}$ Telethon Kids Institute, University of Western Australia, Perth 6009, Australia

Full list of author information is available at the end of the article
}

C C The Author(s). 2021 Open Access This article is licensed under a Creative Commons Attribution 4.0 International License, which permits use, sharing, adaptation, distribution and reproduction in any medium or format, as long as you give appropriate credit to the original author(s) and the source, provide a link to the Creative Commons licence, and indicate if changes were made. The images or other third party material in this article are included in the article's Creative Commons licence, unless indicated otherwise in a credit line to the material. If material is not included in the article's Creative Commons licence and your intended use is not permitted by statutory regulation or exceeds the permitted use, you will need to obtain permission directly from the copyright holder. To view a copy of this licence, visit http://creativecommons.org/licenses/by/4.0/ The Creative Commons Public Domain Dedication waiver (http://creativecommons.org/publicdomain/zero/1.0/) applies to the data made available in this article, unless otherwise stated in a credit line to the data. 


\section{Background}

NUT carcinoma (NC), previously referred to as NUT midline carcinoma (NMC), is a rare and very aggressive cancer that occurs in both children and adults $[1,2]$. NC was first described with the characteristic $t(15 ; 19)$ translocation almost 30 years ago $[3,4]$. Since $\mathrm{NC}$ is rare, not restricted to a particular organ and lacks specific clinical and histomorphological features, the diagnosis is often challenging and misdiagnoses occur $[2,5,6]$. The characteristic translocation $\mathrm{t}(15$; 19) results in the fusion of the NUTM1 gene (previously called $N U T$ ), located at $15 \mathrm{q} 14$, with another gene. In most cases this gene is BRD4 at $19 \mathrm{p} 13$, and various translocation breakpoints have been reported $[1,7-9]$. The remaining cases show translocations between NUTM1 and non-BRD4 genes, including BRD3 or NSD3, or other genes [1, 2, 10-12]. These fusions lead to the formation of oncogenic complexes that, in cell lines, prevent squamous cell differentiation, and alter histone acetylation [11, 13-16].

These translocations appear essential to the development of NC, which is otherwise associated with an apparently simple karyotype. This type of genetic change is seen in many childhood leukemias, some lymphomas and soft tissue tumors, in contrast to the complex karyotypes and multiple genetic events seen in most carcinomas $[13,14]$. NC can affect any age, from neonatal cases $[1,17]$ to older patients. However, many are described in young patients which, with the notable exception of nasopharyngeal carcinoma, is unusual for carcinomas.

$\mathrm{NC}$ is an aggressive and largely chemoresistant disease. A 2012 study reported that 63 patients who were diagnosed with $\mathrm{NC}$ were found to have an overrall survival of 6.7 months; the 2 year progression free survival was $9 \%$ and the overall 2 year survival was $19 \%$ (CI 7-31\%) [18]. A review of the literature showed the overall survival in 119 patients to be only 5 months [19]. Occasional cases with a better outcome are reported [20, 21].

Poorly differentiated tumors requiring immunohistochemistry and/or molecular techniques for diagnosis are not uncommon in pediatric and adolescent patients. However, there remains a small residual heterogeneous group that do not clearly fit into a diagnostic category, and these have a variable prognosis and response to therapy. Tests to exclude NC and other entities such as the Rhabdoid tumor group should be routinely considered. Establishing a diagnosis of a NC tumor is important to enable better management and counselling, so we aimed to conduct a survey to identify NC tumors over a period of 26 years at the only tertiary pediatric institution of the geographically isolated state of Western Australia.

\section{Methods}

We reviewed records from the Pathology and Oncology Department of all patients that presented to the Princess Margaret Hospital for Children Oncology Department from 1989 to 2014 with an undifferentiated or poorly differentiated malignancy. In 2018, the hospital changed name to Perth Children's Hospital (PCH). The Oncology-Haematology Department at $\mathrm{PCH}$ is a member of the North American Children's Oncology Group (COG), and all patients are invited to participate in COG studies (where these are open) or are treated according to previous COG protocols. Tumor specimens were assessed using formalin or B5-fixed material, routine histology and immunohistochemistry, including hematoxylin and eosin (H\&E), cytokeratin AE1\&3, vimentin, CD99, INI, neuron-specific enolase (NSE) [22, 23]. The NUTM1 protein was detected using the C52B1 antibody (Cell Signaling Technology, USA). Microscopy images were acquired using Leica equipment for routine diagnostic microscopy and image acquisition. Samples were taken for cytogenetics and molecular genetic analyses. To select the cases as potential NC for this review, we first identified all patients with an undifferentiated or poorly differentiated malignancy seen at $\mathrm{PCH}$ over the 26-year period. Of those, the histology, immunohistochemistry, cytogenetics and site of tumor allowed diagnosis of most cases. Special consideration was given to cases where an NC was possible, such as poorly differentiated carcinoma in or around the respiratory tract, or where cytogenetic results on review were suggestive of NC. From the mid 1990's, additional targeted molecular tests such as FISH became available clinically, although NUT FISH was not available clinically until 2013. Some of the undifferentiated or poorly differentiated malignancies were found to be newer and previously undescribed entities. Based on the review of all patients with an undifferentiated or poorly differentiated malignancy at $\mathrm{PCH}$ over a 26-year period, fourteen cases remained difficult to classify. At the time of diagnosis, patients or their guardians consented to providing samples for research, including attempts to establish cell lines from tumor material. Ethical approval for the study was obtained from the Human Research Ethics Committee of the Princess Margaret Hospital for Children. $\mathrm{PCH}$ is the only hospital in the state of Western Australia that routinely treats pediatric and adolescent oncology patients aged $0-16$ years. The geography and demographics of Western Australia with a largely urban population in a large state, at very long distances from other urban centers, is an advantage for epidemiological studies. We examined the incidence of this tumor and the main pediatric tumors over 26 years in Western Australia, using denominator data from the Australian Bureau of Statistics (database accessed April 2020) [24]. 


\section{Results}

\section{Patients}

From 1989 to 2014, fourteen cases presenting to $\mathrm{PCH}$ were identified as undifferentiated sarcoma or carcinoma (Table 1). The cases were reviewed with respect to karyotype, histopathology (including immunohistochemistry) and further immunohistochemical staining (for INI and NUTM1 where tissue was available) to determine consistency with NC. Five cases were positively identified as being NC (summarised in Table 2). The remaining cases included two confirmed nasopharyngeal carcinomas (NPCs), three rhabdoid or probable rhabdoid tumors, one INI-negative undifferentiated sarcoma, one malignant solid-type pleuropulmonary blastoma (PPB), and one malignant myxoid undifferentiated tumor (a suspected malignant peripheral nerve sheath tumor, MPNST). One tumor could not be further characterised due to lack of suitablyfixed tissue for immunohistochemistry.

\section{Incidence of NC}

Over the 26 years captured by this review, there was a steady increase in the $0-16$ year old population in
Western Australia, from 419,412 in 1989, to 547,295 in 2014 [24]. From this we determined an estimated incidence of around 0.41 cases per million child years (0-16 years of age) at risk or $1 \mathrm{NC}$ per 2.4 million child-years.

\section{NC case reports \\ Patient 2}

More than 30 years ago, an 11 year-old girl presented with a history of a cough and right shoulder pain. Imaging showed complete opacification of the right hemithorax. There was progressive enlargement of the mass leading to superior vena caval obstruction, complete replacement of the right hemithorax and displacement of the mediastinum to the left. Further investigations showed the mass was locally invasive with no distant metastatic spread. Open lung biopsy showed a poorly differentiated malignant neoplasm with focal squamous differentiation, and immunohistochemistry showed strong cytokeratin positivity (Fig. 1 and Table 2). In 1991 we reported that the intrathoracic carcinoma in this patient showed a translocation $t(15 ; 19)$, which at the

Table 1 Fourteen poorly differentiated or undifferentiated cancers identified from hospital pathology records over 26 years

\begin{tabular}{|c|c|c|c|c|c|c|c|c|c|c|}
\hline $\begin{array}{l}\text { Patient } \\
\text { Case }\end{array}$ & $\begin{array}{l}\text { Age at } \\
\text { diagnosis }\end{array}$ & Gender & Pathology & $\begin{array}{l}\text { Tumor site } \\
\text { (primary) }\end{array}$ & $\begin{array}{l}\text { Chemo } \\
\text { Therapy }^{\mathrm{a}}\end{array}$ & $\begin{array}{l}\text { Radio } \\
\text { therapy }^{b}\end{array}$ & $\begin{array}{l}\text { NUTM1 } \\
\text { staining }\end{array}$ & Diagnosis & Alive & $\begin{array}{l}\text { Time to } \\
\text { death }\end{array}$ \\
\hline 1 & 13 yrs. 9 mo & $M$ & $\begin{array}{l}\text { Undifferentiated } \\
\text { CA }\end{array}$ & Nasopharynx & $C P$ & $Y(C)$ & Neg & NPC & Yes & \\
\hline 2 & 11 yrs. 7 mo & $\mathrm{F}$ & $\begin{array}{l}\text { Undifferentiated } \\
\text { CA }\end{array}$ & Mediastinum & Ifos & $Y(E)$ & Pos & $\mathrm{NC}$ & No & $4.5 \mathrm{Mo}$ \\
\hline 3 & 16 yrs. 7 mo & $F$ & $\begin{array}{l}\text { Undifferentiated } \\
\text { CA }\end{array}$ & Mediastinum & $\mathrm{CP}$ & $Y(C)$ & Pos & $\mathrm{NC}$ & No & 1 yr 3 Mo \\
\hline 4 & 7 yrs. 8 mo & $M$ & $\begin{array}{l}\text { Undifferentiated } \\
\text { CA }\end{array}$ & Larynx & $\mathrm{CP}$ & $Y(C)$ & $\mathrm{Neg}^{\mathrm{c}}$ & NC & No & $10 \mathrm{Mo}$ \\
\hline 5 & 13 yrs. 6 mo & $\mathrm{F}$ & Carcinoma & Nasopharynx & $\mathrm{CP}$ & $Y(E)$ & ND & $?$ & Yes & \\
\hline 6 & 16 yrs. 8 Mo & $\mathrm{F}$ & Carcinoma & Lung & $\mathrm{CP}$ & $Y(C)$ & Pos & $\mathrm{NC}$ & No & $8 \mathrm{Mo}$ \\
\hline 7 & 11 yrs. 8 Mo & $M$ & Carcinoma & Nasopharynx & $\mathrm{CP}$ & $Y(C)$ & $\mathrm{Neg}$ & NPC & Yes & \\
\hline 8 & 5 yrs. 2 Mo & $\mathrm{F}$ & $\begin{array}{l}\text { Undifferentiated } \\
\text { Sarcoma }\end{array}$ & Retroperitoneum & VAC & $Y(C)$ & Neg & $\begin{array}{l}\text { INI neg } \\
\text { sarcoma }\end{array}$ & Yes & \\
\hline 9 & 3 yrs. 5 Mo & $\mathrm{F}$ & $\begin{array}{l}\text { Undifferentiated } \\
\text { Sarcoma }\end{array}$ & Neck & VAC & $Y(C)$ & ND & $\begin{array}{l}\text { Probable } \\
\text { Rhabdoid }\end{array}$ & Yes & \\
\hline 10 & 13 yrs. 3 Mo & $\mathrm{F}$ & Sarcoma & Paraspinal & $\mathrm{CP}$ & $Y(C)$ & ND & ? MPNST & No & $12 \mathrm{Mo}$ \\
\hline 11 & 14 yrs. 2 Mo & $\mathrm{F}$ & $\begin{array}{l}\text { Undifferentiated } \\
\text { Sarcoma }\end{array}$ & Paraspinal & VAC & $Y(C)$ & Pos & NC & No & $2 \mathrm{yrs} .5 \mathrm{Mo}$ \\
\hline 12 & $1 \mathrm{yr} 2 \mathrm{Mo}$ & $M$ & $\begin{array}{l}\text { Undifferentiated } \\
\text { Sarcoma }\end{array}$ & Bladder & VAC & $Y(C)$ & Neg & Rhabdoid & No & 1 yr 3 Mo \\
\hline 13 & 3 yrs. $6 \mathrm{Mo}$ & $\mathrm{F}$ & $\begin{array}{l}\text { Undifferentiated } \\
\text { Sarcoma }\end{array}$ & Lung & VAC & $\mathrm{N}$ & Neg & PPB & No & $8 \mathrm{Mo}$ \\
\hline 14 & $5 \mathrm{Mo}$ & $M$ & $\begin{array}{l}\text { Undifferentiated } \\
\text { Sarcoma }\end{array}$ & Neck & VAC & $Y(C)$ & $\mathrm{Neg}$ & $\begin{array}{l}\text { Probable } \\
\text { Rhabdoid }\end{array}$ & No & $6 \mathrm{yrs} .2 \mathrm{Mo}$ \\
\hline
\end{tabular}

${ }^{a}$ Chemotherapy: (CP) Cisplatinum-based, i.e. Cisplatinum, Doxorubicin, 5FU or Carboplatinum, (Ifos) Ifosfamide, (VAC) Vincristine, Actinomycin and Cyclophosphamide

${ }^{\mathrm{b}}$ Radiotherapy: $(\mathrm{Y})$ yes to primary tumor or $(\mathrm{N})$ no to primary tumor, $(\mathrm{E})$ early with first few cycles or $(\mathrm{C})$ at the end of chemotherapy to consolidate therapy 'Probably technical failure due to fixative

MPNST Malignant peripheral Nerve Sheath Tumor, PPB PleuroPulmonary Blastoma, NPC Nasopharyngeal carcinoma, ND Not determined, CA Carcinoma 
Table 2 Pathology of NC cases and established cell lines

\begin{tabular}{|c|c|c|c|c|c|c|}
\hline Patient & Tumor site & Histopathology ${ }^{a}$ & $\begin{array}{l}\text { Cytokeratin } \\
\text { staining }^{\mathrm{a}}\end{array}$ & $\begin{array}{l}\text { NUTM1 } \\
\text { staining }^{a}\end{array}$ & Cytogenetics of tumor ${ }^{a}$ & $\begin{array}{l}\text { Cell line } \\
\text { established }\end{array}$ \\
\hline 2 & Lung & $\begin{array}{l}\text { Poorly differentiated carcinoma focal squamous } \\
\text { differentiation }\end{array}$ & YES (focal) & YES & $\mathrm{t}(15 ; 19)(\mathrm{q} 14 ; \mathrm{p} 13.1)$ & PER-403 \\
\hline 3 & Sternal mass & $\begin{array}{l}\text { Highly necrotic small cell, poorly differentiated } \\
\text { carcinoma, with focal epithelial differentiation }\end{array}$ & YES (focal) & YES & $\begin{array}{l}46 \text { XX (probably stromal cells } \\
\text { growth rather than tumor) }\end{array}$ & \\
\hline 4 & Nasopharynx & $\begin{array}{l}\text { Poorly differentiated carcinoma, focal abrupt } \\
\text { squamous differentiation }\end{array}$ & $\begin{array}{l}\text { YES (very } \\
\text { focal) }\end{array}$ & $\begin{array}{l}\mathrm{NO} \\
\text { (Technical } \\
\text { problem) }\end{array}$ & $46 \mathrm{XY}, \mathrm{t}(15 ; 19)(? \mathrm{p} 11 ; \mathrm{q} 12)$ & PER-704 \\
\hline 6 & Bronchus & $\begin{array}{l}\text { Highly necrotic small cell, poorly differentiated } \\
\text { carcinoma, with focal epithelial differentiation }\end{array}$ & YES (focal) & YES & $\begin{array}{l}46 \text { XX, t(1;18;7)(q42;q11.2;q21), } \\
\text { t(6;19)(q13;p13.1) } \\
\text { FISH: cryptic BRD4-NUT }\end{array}$ & PER-624 \\
\hline 11 & $\begin{array}{l}\text { Paraspinal } \\
\text { L4 }\end{array}$ & $\begin{array}{l}\text { Small round blue cell tumor, some neural } \\
\text { features }\end{array}$ & $\begin{array}{l}\text { YES (very } \\
\text { focal) }\end{array}$ & YES & 46, XX, t(15;19)(q13;q13.3) & \\
\hline
\end{tabular}

${ }^{\mathrm{a}}$ Tumor specimen from patient

time was a novel finding and of unknown significance [3].

Objective tumor response was noted with combined chemotherapy and radiation, consisting of 5-day courses of ifosfamide and VP16 given at 3-4 week intervals for 3 months, and radiotherapy (Table 3). After the initial tumor response, however, the tumor progressed, and 3 months later the patient presented with buttock pain, and a bone scan revealed lesions in the axial and peripheral skeleton. A course of cisplatinum with VP16 led to a brief symptomatic response, and the patient died 4.5 months after presentation.

\section{Patient 3}

A 16 year-old adolescent girl presented with shortness of breath. She had a locally invasive large mediastinal mass on imaging, which was subsequently biopsied. Further investigations did not show evidence of metastatic disease. The tumor was very poorly differentiated but showed epithelial differentiation by positive immunohistochemistry for high molecular weight cytokeratin (Fig. 2 and Table 2), but negative for low molecular weight cytokeratin and epithelial membrane antigen. Other markers including CD99, S100 and neural markers were negative. She was treated on CCG (Children's Cancer
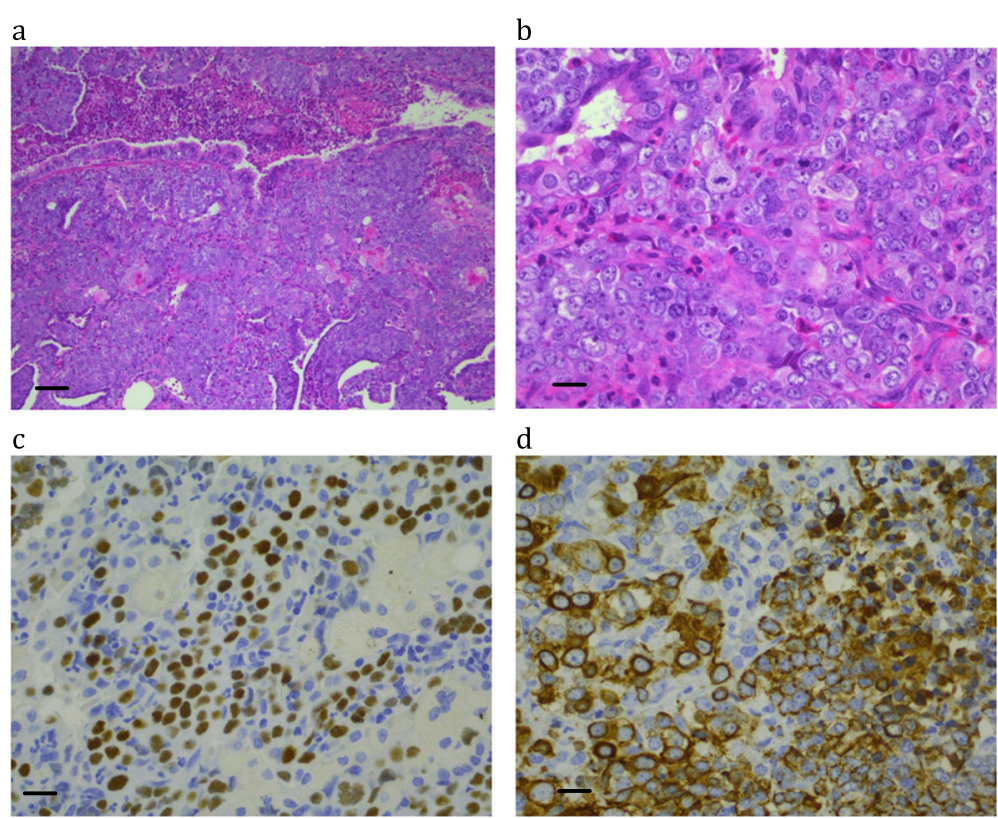

Fig. 1 Patient 2: a poorly differentiated carcinoma with focal squamous differentiation. (a) H\&E $\times 10 ;$ bar $=100 \mu m$ (b) $H \& E \times 40 ; b a r=25 \mu m$; (c) NUTM1 immunohistochemistry $\times 40 ;$ bar $=25 \mu \mathrm{m}$; (d) Cytokeratin AE1\&3 $\times 40 ;$ bar $=25 \mu \mathrm{m}$ 
Table 3 Summary of therapy to NC cases

\begin{tabular}{|c|c|c|c|c|}
\hline Patient & Tumor site & $\begin{array}{l}\text { Year of } \\
\text { diagnosis }\end{array}$ & Chemotherapy & Radiotherapy \\
\hline 2 & Lung & 1989 & Ifosfamide (1800 mg /m2/day) and VP16 (100 mg/m2/day) & $60.4 \mathrm{~Gy}$ \\
\hline 3 & Sternal mass & 1996 & $\begin{array}{l}{ }^{a} \text { CCG 0894: carboplatinum ( } 400 \mathrm{mg} / \mathrm{m} 2 / \text { day), VP16 ( } 100 \mathrm{mg} / \mathrm{m} 2 / \text { day) and } \\
\text { ifosfamide ( } 1800 \mathrm{mg} / \mathrm{m} 2 / \text { day) } \\
\text { Autologous peripheral hematopoietic stem cell rescue with melphalan } \\
\text { ( } 200 \mathrm{mg} / \mathrm{m} 2) \text {. }\end{array}$ & $60.4 \mathrm{~Gy}$ \\
\hline 4 & Nasopharynx & 1996 & $\begin{array}{l}{ }^{a} \text { CCG 0894: carboplatinum ( } 400 \text { mg/m2/day), VP16 (100 mg/m2/day) and } \\
\text { ifosfamide (1800 mg /m2/day) }\end{array}$ & $\begin{array}{l}\text { bIFRT } 75 \text { Gy (supraclavicular fossa) and } \\
52.5 \text { Gy (posterior region of the neck) }\end{array}$ \\
\hline 6 & Bronchus & 2007 & $\begin{array}{l}\text { Five cycles of ifosfamide }(1200 \mathrm{mg} / \mathrm{m} 2 / \text { day) and doxorubicin }(37.5 \mathrm{mg} / \\
\mathrm{m} 2 / \text { day) given with dexrazoxane as cardioprotectant }\end{array}$ & $45 \mathrm{~Gy}$ \\
\hline 11 & $\begin{array}{l}\text { Paraspinal } \\
\text { L4 }\end{array}$ & 1994 & $\begin{array}{l}{ }^{a} \text { CCG } 6902 \text {, vincristine }(1.5 \mathrm{mg} / \mathrm{m} 2) \text {, actinomycin }(0.15 \mathrm{mg} / \mathrm{kg} / \text { day) and } \\
\text { ifosfamide }(1800 \mathrm{mg} / \mathrm{m} 2 / \text { day) } \\
\text { Subsequent to second debulking, cyclophosphamide }(2.2 \mathrm{~g} / \mathrm{m} 2) \text {, VP16 } \\
\text { (100 mg/m2/day). Peripheral hematopoietic stem cell rescue with } \\
\text { melphalan }(200 \mathrm{mg} / \mathrm{m} 2) \text {. }\end{array}$ & $63.8 \mathrm{~Gy}$ \\
\hline
\end{tabular}

${ }^{a}$ CCG Children's Cancer Group

bIFRT involved field radiation therapy

Group) study 0894 for six cycles at 3-4 week intervals (Table 3). Local mediastinal relapse occurred 12 months after diagnosis, confirmed on biopsy, and she was treated with an autologous rescue using melphalan. She progressed and died 15 months after diagnosis. A positive NUTM1 staining was seen on review (Table 2).

\section{Patient 4}

A 7-year old boy presented with a 3-week history of cough, hoarse voice, noisy breathing and a left-sided neck lump. Imaging showed a left anterior irregular and discrete neck mass and a smaller similar lesion present on the right side of the neck. In addition, there was soft tissue thickening of the epiglottis and left aryepiglottic fold and a soft tissue swelling around the upper trachea was seen with some narrowing of the larynx and upper trachea. Further investigations confirmed the masses were locally invasive with some involvement of cervical lymph nodes but no distant metastatic disease was demonstrated.

Multiple biopsies showed histology of a poorly differentiated tumor with no obvious squamous differentiation
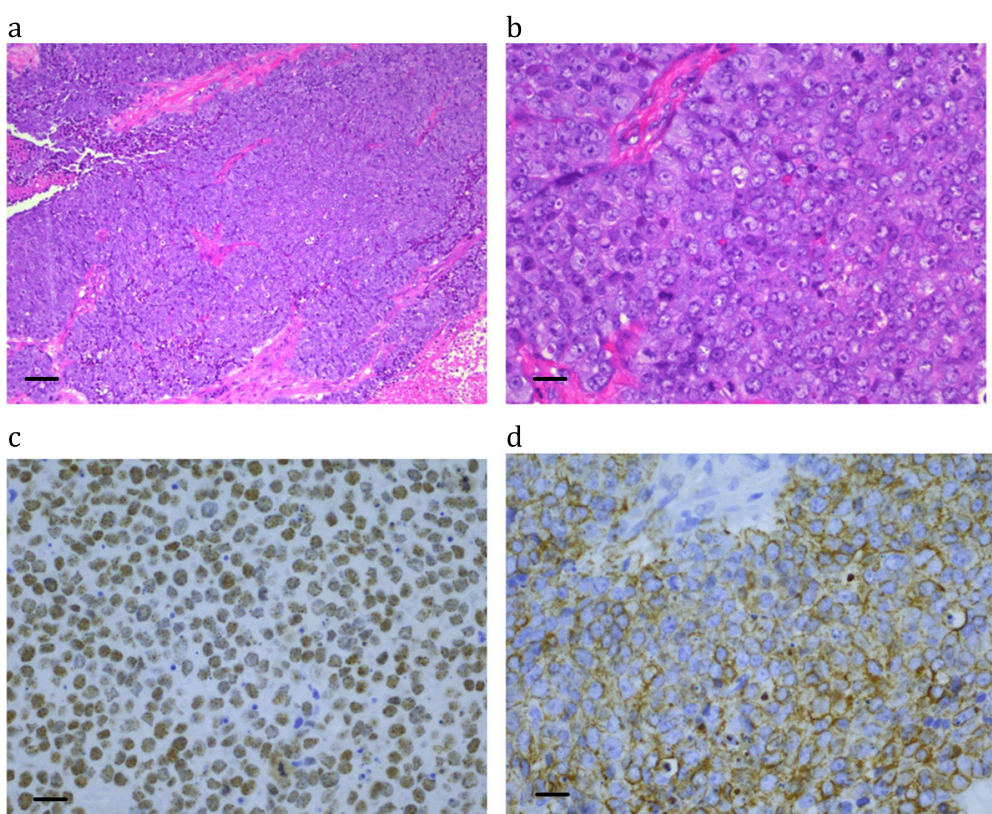

d

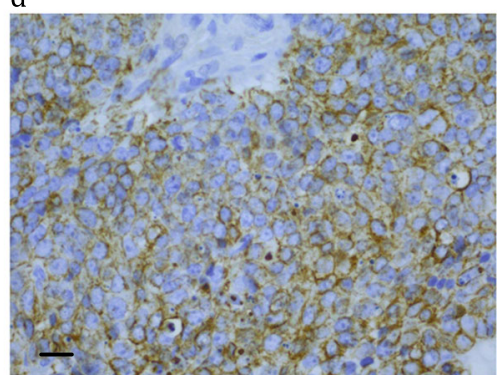

Fig. 2 Patient 3: a highly necrotic small cell, poorly differentiated carcinoma, with focal epithelial differentiation. (a) H\&E $\times 10$; bar $=100 \mu \mathrm{m}$; (b) H\&E $\times 40$; bar = $25 \mu \mathrm{m}$; (c) NUTM1 immunohistochemistry $\times 40$; bar = $25 \mu \mathrm{m}$; (d) Cytokeratin AE1\&3 × 40; bar = $25 \mu \mathrm{m}$ 
(Fig. 3 and Table 2). Immunohistochemistry was equivocal for pan-cytokeratin but negative for low molecular weight cytokeratin, and was negative for CD99, neural markers and vimentin. Progression to the lymph node revealed a locally metastatic tumor with undifferentiated malignant cells, but focal abrupt transition to well differentiated squamous cells. Cytogenetics showed a t $(15 ; 19)$ translocation, however, on review only B5-fixed material was available, and NUTM1 was negative. Metaphases were of poor quality and a more precise breakpoint could not be determined, but since NC translocations can often be complex or cryptic [7, 9, 25], the full reported karyotype (Table 2) does not rule out a NUTM1 translocation.

The patient was treated initially on CCG 0894 given at 3-4 week intervals (Table 3). Following two cycles of therapy, local progression was noted in the right neck and confirmed on imaging. IFRT (involved field radiation therapy) was administered (Table 3). There was resolution of the nodal masses and some resolution of the tracheal infiltration by imaging. At 3 months imaging showed new lesions in the proximal tibias and the head of the right humerus, confirmed by biopsies to be metastatic carcinoma. The patient succumbed ten months after initial diagnosis.

\section{Patient 6}

A 16 year-old girl presented with a 2-week history of cough, fever and right-sided chest pain. Imaging revealed a large right-sided posterior locally invasive mediastinal mass with secondary right middle and lower lobe lung collapse/consolidation. Futher imaging did not demonstrate metastatic disease. The biopsy was very small and largely necrotic (Fig. 4 and Table 2). A diagnosis of poorly differentiated lung carcinoma, possibly $\mathrm{NC}$, was made. A repeat biopsy by direct bronchoscopy showed an extensively necrotic and poorly differentiated tumor, with extensive neutrophil infiltrate, and focal squamous differentiation. The karyotype showed a complex translocation, which included the $B R D 4$ locus. NUTM1 positive staining was confirmed on review (Table 2).

The patient poorly tolerated 5-fluorouracil (5FU) which was part of the initial cycle of combination therapy, and developed 5FU-induced cardiotoxicity. Radiological re-evaluation demonstrated disease progression. Therapy was changed to five cycles of combination intravenous ifosfamide and doxorubicin given with dexrazoxane as cardioprotectant (Table 3), demonstrating clinical and radiological response with this chemotherapy combination. Therapeutic radiotherapy to consolidate response commenced 7 months after diagnosis, but while on radiotherapy thoracic disease recurred, and the patient died of rapidly progressive resistant disease a month later.

\section{Patient 11}

A 14 year-old female presented with a six-week history of right-sided anterior thigh and lower leg pain associated with difficulty of walking, pain and paraesthesia in the lumbar dermatomes 2, 3 and 4, without other associated neurological symptoms. Imaging showed a soft tissue lobulated mass at L4/5 extending through the

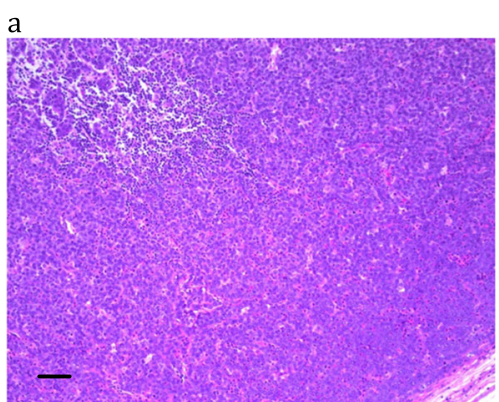

b

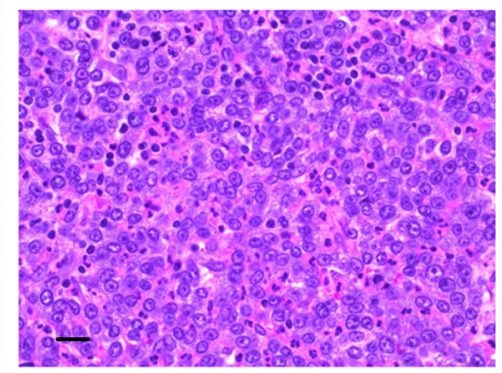

$\mathrm{d}$
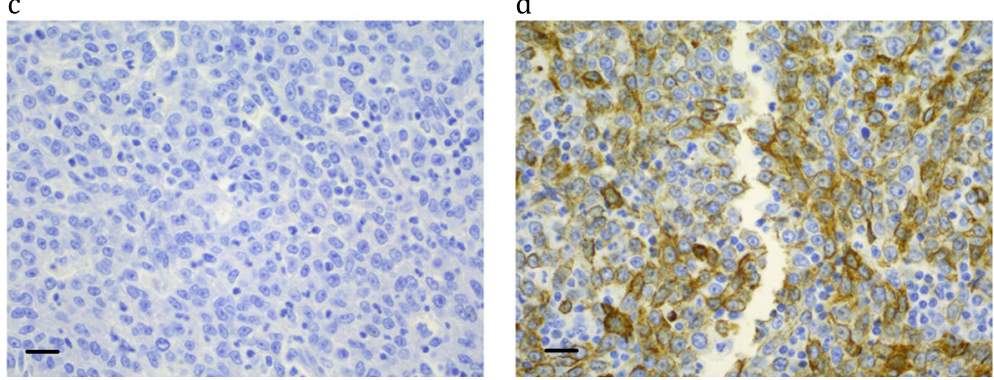

Fig. 3 Patient 4: a poorly differentiated carcinoma with focal abrupt squamous differentiation. (a) H\&E $\times 10$; bar = $100 \mu m$; $(b) H \& E \times 40$; bar = $25 \mu \mathrm{m}$; (c) NUTM1 immunohistochemistry × 40; bar = $25 \mu \mathrm{m}$; (d) Cytokeratin AE1\&3 × 40; bar = $25 \mu \mathrm{m}$ 

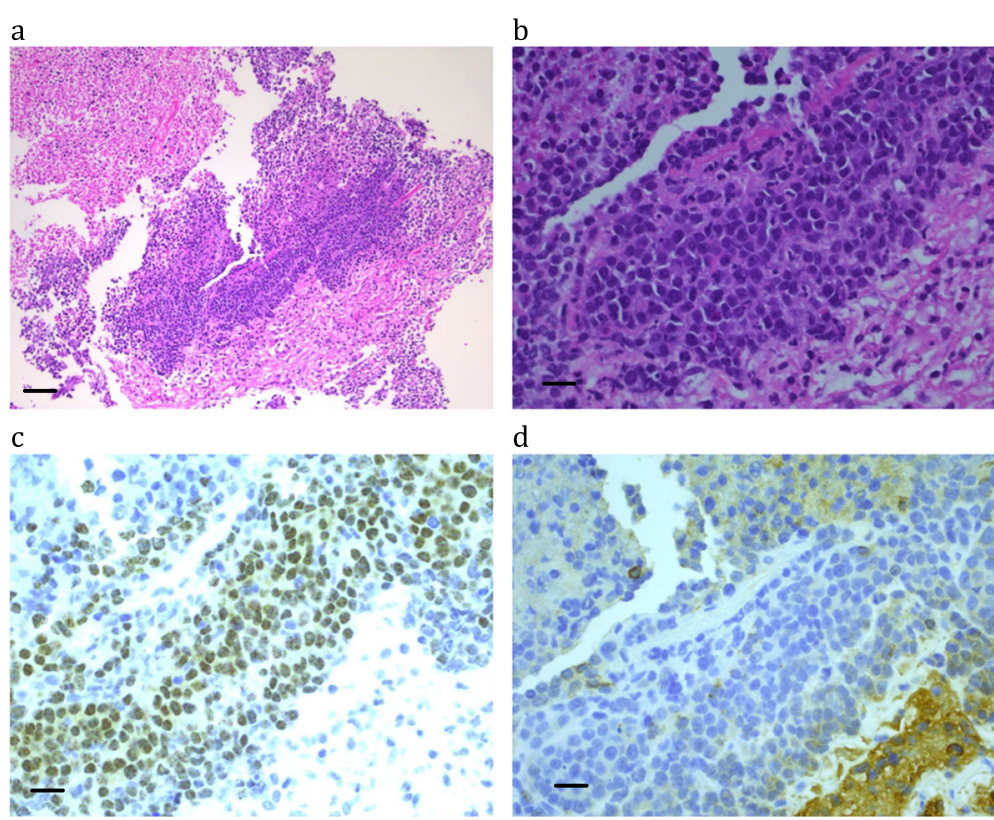

d

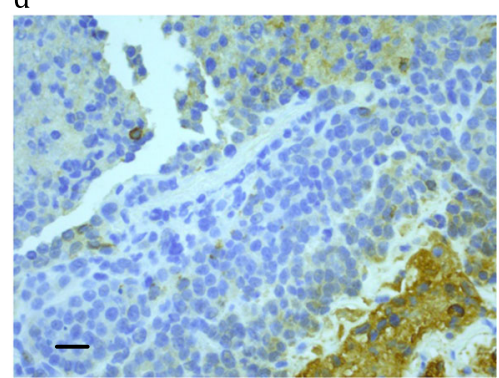

Fig. 4 Patient 6: a highly necrotic small cell, poorly differentiated carcinoma, with focal epithelial differentiation. (a) H\&E $\times 10$; bar $=100 \mu$ m; (b) H\&E $\times$ 40; bar = $25 \mu \mathrm{m}$; (c) NUTM1 immunohistochemistry $\times$ 40; bar $=25 \mu \mathrm{m}$; (d) Cytokeratin AE1\&3 × 40; bar $=25 \mu \mathrm{m}$

foramina into the intradural space with some cord compression. Additional staging did not show any evidence of metastatic disease.

Debulking surgery was performed. The tumor demonstrated sheets of poorly differentiated cells with a focally myxoid stroma and some focal cytokeratin staining, with no obvious epithelial diffentiation microscopically (Fig. 5 and Table 2). There was a hint of neural differentiation with NSE and chromogranin staining. CD99 staining was not performed. Post-surgical CT scans showed a significant residual mass in the epidural space with clearance of the intradural component. Cytogenetics revealed

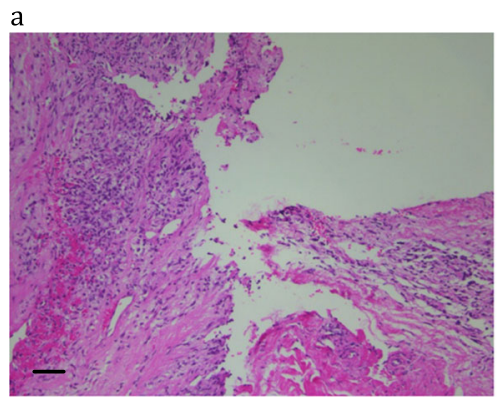

C

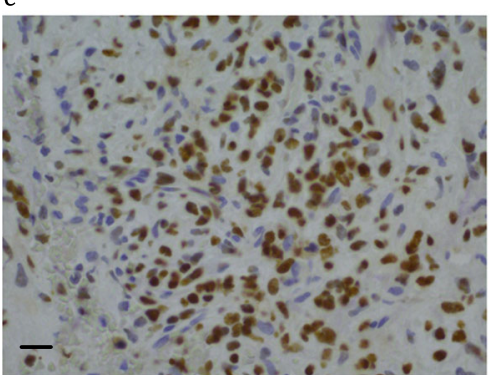

b

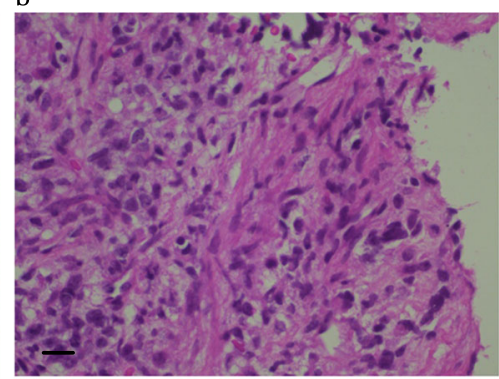

d

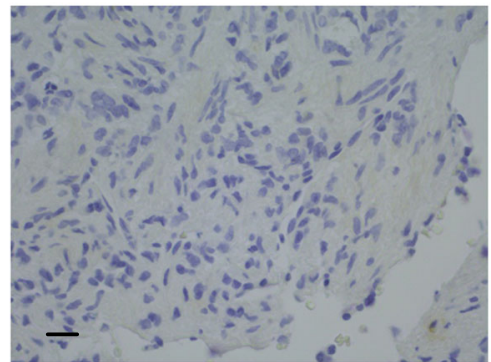

Fig. 5 Patient 11: Small round blue cell tumor with some neural features. (a) H\&E $\times 10$; bar = $100 \mu$ m; (b) H\&E $\times 40$; bar = $25 \mu$ m; (c) NUTM1 immunohistochemistry $\times 40$; bar $=25 \mu \mathrm{m}$; (d) Cytokeratin AE1\&3 $\times 40$; bar $=25 \mu \mathrm{m}$ 
a $t(15 ; 19)$ translocation, however, the precise breakpoint could not be determined from these solid tumor preparations which only ever returned short chromosomes. Since NC translocations can often be complex or cryptic $[7,9,25]$, the full reported karyotype (Table 2) is consistent with a NUTM1 translocation, however the translocation involved the long arm of chromosome 19 and did not appear consistent with a BRD4 rearrangement. At the time of analysis, it was considered possible that the rearrangement was more complex than was reported and that BRD4 might still be rearranged. However, recent reports of CIC-NUTM1 rearrangements [26, 27] with $C I C$ located on the long arm of 19 are more consistent with this patient's karyotype and should be considered as the most likely rearrangement for this patient.

The patient was treated as per CCG protocol 6902 (Table 3). Follow-up imaging, 3 months after commencement of chemotherapy, showed little change in the size of the residual mass, and radiotherapy was commenced to the lumbar vertebrae 3, 4 and 5. Six months after commencement of treatment, imaging demonstrated a persistent residual mass and biopsy confirmed the existence of residual tumor. Further debulking surgery was performed on the residual tumor.

Autologous peripheral hematopoietic stem cell rescue was performed following conditioning therapy (Table 3). At 8 months post stem cell rescue, the patient had pain and paraesthesia in the right thigh and had developed a limp. Imaging showed this mass to be filling L4 and 5 and obscuring the nerve root. The patient refused further surgery. 24 months after initial diagnosis, the patient developed pulmonary metastasis and died several months later. Subsequent immunohistochemistry for NUTM1 at review showed positive nuclear staining (Fig. 5c).

\section{Case summary}

The five patients who had NUTM1-positive tumors were all born in Australia. The only one of the five patients with a family history of cancer was Patient 11, who had a maternal aunt with breast cancer, and the patient's mother also subsequently developed breast carcinoma. Prior to diagnosis, there was no relevant previous history in Patient 11. All five patients with NUTM1-positive tumors died from disease progression. The median time from diagnosis to death from disease within the overall group of undifferentiated tumors was 12 months (4.5 months to 6.2 years) but the median time from diagnosis to death for the NUTM1-positive group was 8 months (4.5 months to 2.4 years).

\section{Summary of the histology and genetics of NC cases}

The histology of the NC cases varied, one had a phenotype similar to a primitive neuroectodermal tumor (PNET), and most were highly cellular and poorly differentiated. Not all showed morphological evidence of squamous differentiation, but when present, this was often focal and abrupt as previously described $[1,13]$. Extensive necrosis was common, sometimes with a prominent neutrophil infiltrate. From Patient 11 there was very little material available, which revealed only a very cellular infiltrative morphology, reminiscent of Ewings Sarcoma (see Fig. 5).

NUTM1 immunohistochemistry positivity typically had a speckled nuclear appearance, was strongest in poorly differentiated areas, and was minimal to absent in the squamous differentiated areas (e.g. Figure 1c, where the paler areas with reduced cellularity and negatively stained nuclei represent tumor cells with obvious squamous differentiation). All cases were positive, except Case 4, where only B5-fixed material was available (Fig. 3c). Cytokeratin staining was typically very focal (e.g. Figure $4 \mathrm{~d}$ ), with only an occasional positive cell, or was completely absent (see Fig. 5d).

The cytogenetic translocation was identified in four cases, however, the archival material often yielded metaphases of poor quality. For Patient 3, a normal karyotype was identified, probably reflecting stromal overgrowth. The tumor material did not allow delineation of the exact translocation breakpoints, but we managed to establish tumor cell lines from three patients (Table 2) which has facilitated more detailed molecular genetic analyses [3, 7-9, 25]. The PER-403 cell line was developed from Patient 2, the first reported case of a translocation $\mathrm{t}(15 ; 19)(\mathrm{q} 14 ; \mathrm{p} 13.1)$ [3]. From Patients 4 and 6 we established PER-704 [8] and PER-624 [7], respectively. Each of these three lines carries a BRD4-NUT translocation as confirmed by RT-PCR, transcriptome sequencing, immunoblot, and immunohistochemistry, although they vary in regard to exact $B R D 4$ breakpoint position.

\section{Discussion}

NC represents a particularly aggressive tumor with a median survival of less than 7 months. Originally it was thought to be a childhood disease, but NC has now been identified in patients ranging from newborn to 78 years $[1,2]$. Since NC is rare, lacks distinct histological features, and is not confined to a particular organ, it is often misdiagnosed. This study aimed to determine the incidence of $\mathrm{NC}$ in pediatric and adolescent patients and to highlight the challenges associated with the diagnosis of NC. Our survey was conducted over a 26 -year period, and was limited to cases identified as undifferentiated sarcoma or carcinoma diagnosed at a single institution in Western Australia. The population of this state is clearly defined, with large distances to other states. The cancer treatment for children and adolescents is centralised, so the ascertainment for the population of around 
2 million is likely to be complete. We were able to find five cases of this rare and aggressive tumor during the reviewed period. No familially-related cases were recognised, but one patient had a family history of breast cancer. Three of the cases were flagged as being $t(15 ; 19)$ translocation carcinomas, or as $\mathrm{NC}$, at the time the patients were diagnosed, and two others were discovered during this review. The numbers confirm that NC is rare. We have calculated an estimated rate of around 0.41 per million years at risk for children ( $0-16$ years). Although there may be some factor that makes Western Australia a high risk for childhood NC, it is most likely that this high ascertainment relates to the practice at $\mathrm{PCH}$ of routinely performing cytogenetic analyses of pediatric tumors in Western Australia. The issue of under-recognition, varying by location, is also suggested by the review of Bauer et al. [18], with six cases reported in Massachussets (population 6.5 million in 2010), but only three in the much larger state of California (population 37 million in 2010).

Four patients presented with tumors in the airways and one in the spine, the latter being unusual. Distant bony metastases were seen in two cases, but all cases were highly aggressive. NPC represents a third of all cancers in the upper airways in children and adolescents, and this is a main differential diagnosis of NC. Most of these are not NCs and are associated with Epstein Barr Virus $[28,29]$. They are usually not resectable and have some local spread. Despite this, the prognosis for nonNC NPC is now much better. In a recent study, the 5year overall survival was $80.9 \%$, the progression-free survival was $79.3 \%$, and five of the reported patients had distant metastatic disease [30]. Since this is very different to the poorer outcome seen in NC, suspected NPC tumors should be routinely screened for NUTM1 positivity to rule out a diagnosis of NC.

In the present study, Patient 11 had the longest duration of remission. The tumor was initially diagnosed as a para-spinal PNET, but the cytogenetic analysis showed a $\mathrm{t}(15 ; 19)$ (q13; 1 13.3) translocation, and the tumor was positive for the NUTM1 protein on review. No cell line was derived from this patient and so we were unable to investigate the nature of the fusion. Recent reports [26, 27] of CIC-NUTM1 translocations are consistent with this patient's karyotype however and this case may thus represent this newly reported entity. Interestingly, there is another patient described in the literature with a PNET in the iliac bone that was $t(15 ; 19)$ positive, and this patient is known to have the longest survival published to date [20].

The differential diagnosis of a malignant undifferentiated tumor in childhood that shows some evidence of epithelial differentiation by immunohistochemistry is wide and includes PNET, rhabdomyosarcoma-which may occasionally show cytokeratin positivity [31] -rhabdoid tumor, epithelioid sarcoma, desmoplastic small round cell tumor [32], synoval sarcoma, and germ cell tumor. Over the past five decades, the number of tumor entities has grown enormously, and tumors are now classified by their clinical presentation, morphology, immunohistochemistry, as well as molecular studies. NUTM1-positive carcinoma has been found increasingly, and is now described in all ages [17, 18].

The poor clinical outcome of $\mathrm{NC}$ patients has prompted studies to determine whether the timing of standard therapy may influence the duration of remission. In a review of 63 patients diagnosed with NC, longer survival times were seen in those who were treated with early radiation therapy and had good surgical resection of the tumor [18]. The median overall survival for patients with $\mathrm{NC}$ was 6.7 months and was not related to histology, sex, location or lymph node involvement. The chemotherapy protocol was not shown to make any difference. In the present study, three of the patients with NC did have early radiation as part of their therapy, however, this did not appear to affect their duration of remission.

Given the dismal outcome for NC, it is urgent to define better treatment options for patients. The search for targeted therapies is severely hampered because $\mathrm{NC}$ is rare, and model systems are limited. In this context, cell lines grown from NC tumor samples play a critical role in helping to elucidate the biology of this disease and the identification of potential treatments $[3,7-9,11,15$, $16,25]$. Two classes of drugs have been found to show activity against NC. They include direct inhibitors of the BRD4 portion of the fusion protein, termed BET inhibitors (iBETs) [1, 33-37]. The others are histone deacetylase inhibitors (HDACs), which promote chromatin acetylation in NC cells, resulting in squamous differentiation and in vitro growth arrest [1,33]. Novel iBET drugs are currently in clinical development and are demonstrating anti-NC activity, with the possibility of integrating these drugs in combination schedules [38].

In two previous investigations, the NC cell lines established from patients in this and other studies were subjected to systematic screening of established and novel antitumor agents $[8,25]$. The results indicated that microtubule inhibitors, topoisomerase inhibitors, anthracyclines, and the CDK9 inhibitor flavopiridol are highly cytotoxic in NC cell lines. An extensive screening of kinase inhibitors in a large panel of tumor cell lines also identified CDK9 inhibitors as being particularly cytotoxic for NC cells [39]. We previously reported the response of NC cells to iBETs to vary considerably [25]; the cytotoxic effect of iBETs was an order of magnitude higher in cell lines with BRD4-NUTM1 (exon11:exon2) translocations compared to those with other BRD4-NUTM1 
translocation variants. The data demonstrated that beside the translocation breakpoint, other biological signals in the genome contribute to the drug response in NC cells, suggesting that therapy options for patients with $\mathrm{NC}$ should take the molecular genetic features of each tumor into account.

\section{Conclusion}

In summary, $\mathrm{NC}$ is a rare and aggressive tumor that can be difficult to diagnose. This 26-year survey in a geographically isolated state with a well-defined population, allowed us to determined an estimated incidence of $\mathrm{NC}$ of around 0.41 per million child years $(0-16$ yrs. of age) at risk. Our survey of pediatric patients with undifferentiated and difficult-to-categorise malignant tumors supports the contention that a significant number of children with $\mathrm{NC}$ in the past may have been misclassified. Immunohistochemistry for NUTM1 is clearly indicated in the assessment of a poorly differentiated pediatric tumor to confirm diagnosis, as well as the analysis of other genetic features to allow better counselling and consideration of novel treatment options.

\section{Abbreviations \\ NUT/NUTM1: Nuclear Protein in Testis; NC: NUT carcinoma; NMC: NUT midline carcinoma; PCH: Perth Children's Hospital; COG: Children's Oncology Group; H\&E: Hematoxylin and eosin; NSE: Neuron-specific enolase; NPC: Nasopharyngeal carcinomas; PPB: Pleuropulmonary blastoma; MPNS T: Malignant peripheral nerve sheath tumor; CCG: Children's Cancer Group; CT: Computed axial tomography; IFRT: Involved field radiation therapy; FISH: Fluorescence in situ hybridization; MRI: Magnetic resonance imaging; PNET: Primitive neuroectodermal tumor; iBET: BET inhibitor; HDAC: Histone deacetylase inhibitor}

\section{Acknowledgements}

We thank Tanya Grumball for the cytogenetic analyses.

\section{Authors' contributions}

TC: Conceptualization; Data curation; Investigation; Writing-original draft; Writing-review \& editing. MC: Data curation; Investigation; Methodology; Writing-review \& editing. AM: Conceptualization; Data curation; Investigation; Writing-original draft; Writing-review \& editing. AHB: Conceptualization; Data curation; Investigation; Writing-original draft; Writing-review \& editing. NdK: Data curation; Investigation; Writing-review \& editing. AC: Conceptualization; Data curation; Investigation; Methodology; Visualization; Writing- original draft; Writing-review \& editing. URK: Conceptualization; Data curation; Formal analysis; Funding acquisition; Investigation; Project administration; Writingoriginal draft; Writing-review \& editing. All authors have read and approved the manuscript.

\section{Funding}

The study was funded by the Children's Leukaemia and Cancer Research Foundation, Western Australia, Australia (AHB, URK).

\section{Availability of data and materials}

All data generated and analyzed during this study are included in the submitted article, hence there are no additional datasets that could be made available.

\section{Declarations}

\section{Ethics approval and consent to participate}

Ethical approval for the study was obtained under Reference Number 90EP from the Human Research Ethics Committee of the Princess Margaret
Hospital for Children, and no further administrative permissions were required to access the raw data. Consent to participate was given by patients or guardians.

\section{Consent for publication}

Written consent to participate included permission to access specimens and clinical details, and to publish findings.

\section{Competing interests}

The authors declare no competing interest.

\section{Author details}

${ }^{1}$ Perth Children's Hospital, Perth 6009, Australia. ${ }^{2}$ PathWest, Nedlands, 6009 Perth, Western Australia. ${ }^{3}$ Telethon Kids Institute, University of Western Australia, Perth 6009, Australia. ${ }^{4}$ Department of Pathology, Sidra Medical and Research Center, PO Box 26999, Doha, Qatar.

Received: 6 September 2020 Accepted: 2 June 2021

Published online: 27 June 2021

\section{References}

1. French CA. NUT carcinoma: Clinicopathologic features, pathogenesis, and treatment. Pathol Int. 2018;68(11):583-95. https://doi.org/10.1111/pin.12727.

2. Huang QW, He $\amalg$, Zheng S, Liu T, Peng BN. An overview of molecular mechanism, Clinicopathological factors, and treatment in NUT carcinoma. Biomed Res Int. 2019;2019:1018439.

3. Kees UR, Mulcahy MT, Willoughby ML. Intrathoracic carcinoma in an 11year-old girl showing a translocation t(15;19). Am J Pediatr Hematol Oncol. 1991;13(4):459-64. https://doi.org/10.1097/00043426-199124000-00011.

4. Kubonishi I, Takehara N, Iwata J, Sonobe H, Ohtsuki Y, Abe T, et al. Novel $\mathrm{t}(15 ; 19)(\mathrm{q} 15 ; \mathrm{p} 13)$ chromosome abnormality in a thymic carcinoma. Cancer Res. 1991:51(12):3327-8.

5. Gokmen-Polar Y, Kesler K, Loehrer PJ Sr, Badve S. NUT midline carcinoma masquerading as a Thymic carcinoma. J Clin Oncol. 2016;34(14):e126-9. https://doi.org/10.1200/JCO.2013.51.1741.

6. Lemelle L, Pierron G, Freneaux P, Huybrechts S, Spiegel A, Plantaz D, et al. NUT carcinoma in children and adults: A multicenter retrospective study. Pediatr Blood Cancer. 2017;64(12). https://doi.org/10.1002/pbc.26693.

7. Thompson-Wicking K, Francis RW, Stirnweiss A, Ferrari E, Welch MD, Baker E, et al. Novel BRD4-NUT fusion isoforms increase the pathogenic complexity in NUT midline carcinoma. Oncogene. 2013;32(39):4664-74. https://doi.org/1 0.1038/onc.2012.487.

8. Beesley AH, Stirnweiss A, Ferrari E, Endersby R, Howlett M, Failes TW, et al. Comparative drug screening in NUT midline carcinoma. Br J Cancer. 2014; 110(5):1189-98. https://doi.org/10.1038/bjc.2014.54.

9. Stirnweiss A, McCarthy K, Oommen J, Crook ML, Hardy K, Kees UR, et al. A novel BRD4-NUT fusion in an undifferentiated sinonasal tumor highlights alternative splicing as a contributing oncogenic factor in NUT midline carcinoma. Oncogenesis. 2015;4(11):e174. https://doi.org/10.1038/oncsis.201 5.33.

10. Stevens TM, Morlote D, Xiu J, Swensen J, Brandwein-Weber M, Miettinen MM, et al. NUTM1-rearranged neoplasia: a multi-institution experience yields novel fusion partners and expands the histologic spectrum. Mod Pathol. 2019;32(6):764-73. https://doi.org/10.1038/s41379-019-0206-z.

11. French CA, Ramirez CL, Kolmakova J, Hickman TT, Cameron MJ, Thyne ME, et al. BRD-NUT oncoproteins: a family of closely related nuclear proteins that block epithelial differentiation and maintain the growth of carcinoma cells. Oncogene. 2008;27(15):2237-42. https://doi.org/10.1038/sj.onc.1210852.

12. French CA, Rahman S, Walsh EM, Kuhnle S, Grayson AR, Lemieux ME, et al. NSD3-NUT fusion oncoprotein in NUT midline carcinoma: implications for a novel oncogenic mechanism. Cancer Discovery. 2014;4(8):928-41. https:// doi.org/10.1158/2159-8290.CD-14-0014.

13. French CA. Pathogenesis of NUT midline carcinoma. Annu Rev Pathol. 2012; 7(1):247-65. https://doi.org/10.1146/annurev-pathol-011811-132438.

14. Schwartz BE, Hofer MD, Lemieux ME, Bauer DE, Cameron MJ, West NH, et al. Differentiation of NUT midline carcinoma by epigenomic reprogramming. Cancer Res. 2011;71(7):2686-96. https://doi.org/10.1158/0008-5472.CAN-10-3 513.

15. Reynoird N, Schwartz BE, Delvecchio M, Sadoul K, Meyers D, Mukherjee C, et al. Oncogenesis by sequestration of CBP/p300 in transcriptionally inactive 
hyperacetylated chromatin domains. EMBO J. 2010;29(17):2943-52. https:// doi.org/10.1038/emboj.2010.176.

16. Alekseyenko AA, Walsh EM, Wang X, Grayson AR, Hsi PT, Kharchenko PV, et al. The oncogenic BRD4-NUT chromatin regulator drives aberrant transcription within large topological domains. Genes Dev. 2015;29(14): 1507-23. https://doi.org/10.1101/gad.267583.115.

17. Shehata BM, Steelman CK, Abramowsky CR, Olson TA, French CA, Saxe DF, et al. NUT midline carcinoma in a newborn with multiorgan disseminated tumor and a 2-year-old with a pancreatic/hepatic primary. Pediatr Dev Pathol. 2010;13(6):481-5. https://doi.org/10.2350/09-10-0727-CR.1.

18. Bauer DE, Mitchell CM, Strait KM, Lathan CS, Stelow EB, Luer SC, et al. Clinicopathologic features and long-term outcomes of NUT midline carcinoma. Clin Cancer Res. 2012;18(20):5773-9. https://doi.org/10.1158/1 078-0432.CCR-12-1153

19. Giridhar P, Mallick S, Kashyap L, Rath GK. Patterns of care and impact of prognostic factors in the outcome of NUT midline carcinoma: a systematic review and individual patient data analysis of 119 cases. Eur Arch Otorhinolaryngol. 2018;275(3):815-21. https://doi.org/10.1007/s00405-018-4 882-y.

20. Mertens F, Wiebe T, Adlercreutz C, Mandahl N, French CA. Successful treatment of a child with t(15;19)-positive tumor. Pediatr Blood Cancer. 2007:49(7):1015-7. https://doi.org/10.1002/pbc.20755.

21. Vorstenbosch L, Mavinkurve-Groothuis AMC, van den Broek G, Flucke U, Janssens GO. Long-term survival after relapsed NUT carcinoma of the larynx. Pediatr Blood Cancer. 2018;65(5):e26946. https://doi.org/10.1002/pbc.26946.

22. lacobelli JF, Charles AK, Crook M, Stewart CJ. NUT protein immunoreactivity in ovarian germ cell tumours. Pathology. 2015;47(2):118-22. https://doi.org/1 0.1097/PAT.0000000000000208.

23. Williams $J H$, Mepham BL, Wright DH. Tissue preparation for immunocytochemistry. J Clin Pathol. 1997;50(5):422-8. https://doi.org/10.113 6/jcp.50.5.422.

24. Statistics ABo: 3101.0 - Australian Demographic Statistics, Mar 2015. In., vol. Tables 2002 to 2017 and Past-Releases, 24/09/15 edn. http://www.abs.gov.a u: Australian Bureau of Statistics; 2015.

25. Stirnweiss A, Oommen J, Kotecha RS, Kees UR, Beesley AH. Moleculargenetic profiling and high-throughput in vitro drug screening in NUT midline carcinoma-an aggressive and fatal disease. Oncotarget. 2017;8(68): 112313-29. https://doi.org/10.18632/oncotarget.22862.

26. Schaefer IM, Dal Cin P, Landry LM, Fletcher CDM, Hanna GJ, French CA. CICNUTM1 fusion: a case which expands the spectrum of NUT-rearranged epithelioid malignancies. Genes Chromosom Cancer. 2018;57(9):446-51. https://doi.org/10.1002/gcc.3.

27. Le Loarer F, Pissaloux D, Watson S, Godfraind C, Galmiche-Rolland L, Silva K, et al. Clinicopathologic features of CIC-NUTM1 sarcomas, a new molecular variant of the family of CIC-fused sarcomas. Am J Surg Pathol. 2019;43(2): 268-76. https://doi.org/10.1097/PAS.0000000000001187.

28. Fang W, French CA, Cameron MJ, Han Y, Liu H. Clinicopathological significance of NUT rearrangements in poorly differentiated malignant tumors of the upper respiratory tract. Int J Surg Pathol. 2013;21(2):102-10. https://doi.org/10.1177/1066896912451651.

29. Stelow EB, Bellizzi AM, Taneja K, Mills SE, Legallo RD, Kutok JL, et al. NUT rearrangement in undifferentiated carcinomas of the upper aerodigestive tract. Am J Surg Pathol. 2008;32(6):828-34. https://doi.org/10.1097/PAS 0b013e31815a3900.

30. Casanova M, Bisogno G, Gandola L, Cecchetto G, Di Cataldo A, Basso E, et al. A prospective protocol for nasopharyngeal carcinoma in children and adolescents: the Italian rare tumors in pediatric age (TREP) project. Cancer. 2012;118(10):2718-25. https://doi.org/10.1002/cncr.26528.

31. Weinreb I, Goldstein D, Perez-Ordonez B. Primary extraskeletal Ewing family tumor with complex epithelial differentiation: a unique case arising in the lateral neck presenting with Horner syndrome. Am J Surg Pathol. 2008; 32(11):1742-8. https://doi.org/10.1097/PAS.0b013e3181706252.

32. Bahrami A, Gown AM, Baird GS, Hicks MJ, Folpe AL. Aberrant expression of epithelial and neuroendocrine markers in alveolar rhabdomyosarcoma: a potentially serious diagnostic pitfall. Mod Pathol. 2008;21(7):795-806. https:// doi.org/10.1038/modpathol.2008.86

33. Stathis A, Zucca E, Bekradda M, Gomez-Roca C, Delord JP, de La Motte RT, et al. Clinical response of carcinomas harboring the BRD4-NUT Oncoprotein to the targeted Bromodomain inhibitor OTX015/MK-8628. Cancer Discovery. 2016:6(5):492-500. https://doi.org/10.1158/2159-8290.CD-15-1335.
34. Filippakopoulos P, Qi J, Picaud S, Shen Y, Smith WB, Fedorov O, et al. Selective inhibition of BET bromodomains. Nature. 2010;468(7327):1067-73. https://doi.org/10.1038/nature09504.

35. Filippakopoulos P. What is the BET on solid tumors? J Clin Oncol. 2018; 36(30):3040-2. https://doi.org/10.1200/JCO.2018.78.8695.

36. Lewin J, Soria JC, Stathis A, Delord JP, Peters S, Awada A, et al. Phase Ib trial with Birabresib, a small-molecule inhibitor of Bromodomain and Extraterminal proteins, in patients with selected advanced solid tumors. J Clin Oncol. 2018;36(30):3007-14. https://doi.org/10.1200/JCO.2018.78.2292.

37. Alqahtani A, Choucair K, Ashraf M, Hammouda DM, Alloghbi A, Khan T, et al. Bromodomain and extra-terminal motif inhibitors: a review of preclinical and clinical advances in cancer therapy. Future Sci OA. 2019;5(3):FSO372. https://doi.org/10.4155/fsoa-2018-0115.

38. Liao S, Maertens O, Cichowski K, Elledge SJ. Genetic modifiers of the BRD4NUT dependency of NUT midline carcinoma uncovers a synergism between BETis and CDK4/6is. Genes Dev. 2018;32(17-18):1188-200. https://doi.org/1 $0.1101 / \mathrm{gad} .315648 .118$.

39. Bragelmann J, Dammert MA, Dietlein F, Heuckmann JM, Choidas A, Bohm S, et al. Systematic kinase inhibitor profiling identifies CDK9 as a synthetic lethal target in NUT midline carcinoma. Cell Rep. 2017;20(12):2833-45. https://doi.org/10.1016/j.celrep.2017.08.082.

\section{Publisher's Note}

Springer Nature remains neutral with regard to jurisdictional claims in published maps and institutional affiliations.

\section{Ready to submit your research? Choose BMC and benefit from:}

- fast, convenient online submission

- thorough peer review by experienced researchers in your field

- rapid publication on acceptance

- support for research data, including large and complex data types

- gold Open Access which fosters wider collaboration and increased citations

- maximum visibility for your research: over $100 \mathrm{M}$ website views per year

At $\mathrm{BMC}$, research is always in progress.

Learn more biomedcentral.com/submissions 